\title{
Currency internationalisation: analytical and policy issues
}

\author{
Hans Genberg ${ }^{1}$
}

\section{Introduction}

The special role of the US dollar in the international monetary system has fascinated politicians, economists and journalists, as well as members of the general public. General de Gaulle complained about "the exorbitant privilege" associated with the role of the dollar as a reserve currency, and others have spoken about the "hegemony of the dollar" to conjure up notions of power and control related to the widespread use of the dollar in international transactions. $^{2}$

When the euro was introduced, there was much talk about how it might challenge the role of the dollar, and predictions have been made about when the euro will overtake the dollar as the premier official international reserve asset. ${ }^{3}$ More recently, with the emergence of China as a major economic power, the possibility that the renminbi will become a major international, or at least regional, currency has been mentioned. ${ }^{4}$

Viewing currency internationalisation as a race between competing currencies raises at least two issues: what determines the evolution of the international use of a currency, and whether there is a case for policy interventions to promote such use. In this paper, I will attempt to address the second of these issues. To anticipate one contention of what follows, I will argue that authorities should not focus their attention on climbing the currency internationalisation charts. Instead, they should consider the pros and cons of policies and institutional changes that may pave the way for the private adoption of the currency in international transactions. The reason for this is that full internationalisation of a currency will not come about unless a certain number of prerequisites are met. Arguably, the most important of those is that there be no restrictions on cross-border transfers of funds and no restrictions on third-party use of the currency in contracts and settlements of trade in goods or assets, or on assets denominated in the currency in private or official portfolios. Other prerequisites are also important, such as the existence of a deep and dynamic domestic financial market, a wellrespected legal framework for contract enforcement, and stable and predictable macro and microeconomic policies

Most of these attributes are, without doubt, desirable in their own right, but in respect of complete freedom of international capital movements, reservations have been made, because of its alleged potential contribution to macroeconomic instability. Hence, before

1 Executive Director, Hong Kong Monetary Authority. The opinions expressed in this paper are those of the author and do not necessarily reflect those of the Hong Kong Monetary Authority.

2 There exists a vast literature on the evolution of reserve currencies as well as other aspects of international currencies. Eichengreen (2005) provides a valuable historical perspective. It is not the purpose here to provide yet another account of the evolution of thought on this topic. Instead, an attempt is made to focus the discussion on the implications for public policy towards currency internationalisation.

3 See Chinn and Frankel (2008) for an assessment of the role of the euro relative to the dollar in official international reserves. Moss (2009) provides a broader assessment.

4 Li and Liu (2007), Chen et al (2009). 
considering steps to attempt to internationalise a currency, policymakers need to take a stance on the desirability of achieving capital account convertibility.

Of course, even if the prerequisites are met, there is no guarantee that currency internationalisation will spontaneously follow. Economies of scale in the use of an international currency, be they due to so-called network externalities or other causes, suggest that the world can sustain only a limited number of international currencies. ${ }^{5}$ This then raises the question of whether authorities in a jurisdiction should take steps to promote the internationalisation of the currency it issues. Answering this question requires both an assessment of the size of the benefits of currency internationalisation per se - ie of the benefits that go beyond the establishment of the prerequisites - and a view on whether there exist externalities which imply that the actions of the private sector alone are not sufficient for the economy as a whole to reap the full benefits of currency internationalisation. My own assessment is that the case for policy intervention focused explicitly on promoting the internationalisation of a currency is not overwhelming.

My analysis will start by recalling briefly the main features, benefits and costs of currency internationalisation as identified in the literature. I will examine the nature of the alleged benefits and argue that, in some cases at least, they are not as self-evident as might appear at first sight. I will then turn to the question of whether there is a case for policy intervention, focusing first on the issue of international capital mobility before asking whether public policy should actively seek to promote the international use of a currency.

A separate section is devoted to a discussion of the number of international currencies there could be, and what role there might be for regional currencies. Here, I hypothesise that changes in the international payments infrastructure will make it increasingly possible for several international currencies to coexist. As a consequence, any exorbitant privilege of being the world's dominant currency is likely to be a thing of the past.

\section{Currency internationalisation: a brief review of the facets, benefits and costs}

I start with a review of the main aspects of currency internationalisation as identified in the literature. Kenen's contribution to this seminar already contains the main arguments, which allows me to be very brief. ${ }^{6}$ Perhaps the most visible aspect of the internationalisation of a currency is when it is readily and frequently used in transactions among non-residents outside the jurisdiction where the currency is issued. Examples are the quotation and payment of real estate in some countries using US dollars, the use of US dollars by tourists in countries in which it is not the legal tender, and the payment of illegal drug transactions outside the United States with bundles of US\$100 bills, to mention just a few. The benefit to the issuing country from this type of currency internationalisation is the seigniorage gains associated with the additional demand for the physical currency. The benefit to the user includes a relatively high real value of a readily accepted note (eg the $\$ 100$ bill), the widespread international acceptance of the currency for transactions, and the relative stability as a store of value.

A second and more subtle aspect of the international use of a currency is in the denomination and invoicing of international trade. Grassman's Law (the idea that the invoicing currency in international trade tends to be that of the exporting country)

\footnotetext{
Section 4 discusses this issue further.
}

6 Kenen (2009). 
notwithstanding, a disproportionate amount of world trade tends to be denominated in US dollars, especially when the trade involves jurisdictions whose currencies are not fully convertible, thus making the hedging of exchange rate risk more difficult. It is often suggested that this practice confers a benefit on US exporters and importers in that they face lower currency risk. Below, I will contend that this argument is less general than it appears at first sight.

Third, international borrowing and lending may be denominated in a currency which is different from that used in the jurisdiction of either the borrower or the lender. This may be referred to as a case of full internationalisation of a currency as far as asset trade is concerned. We may refer to partial internationalisation when a borrower is able to denominate bond issues sold to foreign investors in the borrower's currency, but where this currency is not used between third parties. The nature and distribution of the gains associated with full and partial currency internationalisation in the sense just defined are related to both the potential reduction in borrowing costs due to the larger size of the market for debt denominated in a particular currency and to the potential diversification gains. As these gains are intimately linked with those that obtain from freedom of international capital movements (regardless of currency denomination), I will discuss them in some detail in a subsequent section.

A final aspect of currency internationalisation relates to its inclusion (or more precisely the inclusion of assets denominated in the currency) in official reserve holdings. This differs from the previous aspect mainly because of the nature of the lender, but there also seems to be an element of status involved, at least if one judges by references to rankings of currencies in terms of the proportion they account for in official reserves, and by studies which focus on whether and when a currency might overtake another in the ranking. Of course, the focus on official reserve holdings may also be due to the fact that relatively accurate data on such holdings are available, whereas they are not for holdings in private portfolios.

Countries have, at times, tried to discourage the use of the domestic currency internationally because of the perceived costs that may be associated with such use. For example, during the time when the Deutsche Bundesbank and the Swiss National Bank focused their monetary policy strategies on the control of monetary aggregates, it was feared that greater international use of the Deutsche mark or the Swiss franc would render the demand for money less stable and therefore complicate the setting of the appropriate target growth rate for the supply. In a context where policy is focused on setting a short-term interest rate, the concern for the stability of the money demand is of less relevance. However, it may be argued that international use of the currency could render the exchange rate more volatile and therefore complicates the task of finding the appropriate level of the policy interest rates. I will argue below that both of these concerns have more to do with removing restrictions on the international mobility of capital than with currency internationalisation in the strict sense.

The same is true, I would argue, for a second cost sometimes ascribed to currency internationalisation - especially that which is associated with international bond issues namely, that domestic interest rates would become more dependent on external factors. This should, I contend, be analysed primarily in relation to the freeing-up of international capital flows. ${ }^{7}$

7 The concern over external influences on domestic interest rates has recently been directly linked to official reserve holdings and, in particular, the investment strategies of sovereign wealth funds. It is debatable whether official portfolio management strategies give rise to more interest rate uncertainty than those of the private sector. Be that as it may, I will not pursue this topic further here. 


\section{Analytical and policy Issues}

In the previous section, I alluded to two issues on which I believe there is some ambiguity in the literature. The first relates to the significance of the denomination of trade for the benefits of currency internationalisation and the second, and more important issue, concerns the distinction between freedom of movement of capital and currency internationalisation. In this section, I discuss these issues in turn, before moving to the question of whether there is a case to be made for policy intervention to promote the internationalisation of a currency.

\subsection{Currency denomination and invoicing of trade}

Much of international trade is denominated and/or invoiced in US dollars. This is the case even for trade which does not involve the United States either as a buyer or as a seller. What are the implications of this widespread use of the US dollar? They are not as straightforward as might be imagined at first sight. Consider, first, the case of trade involving the United States. It might be thought that when US exports or imports are priced in US dollars, the corresponding US firm will benefit because it will not face any currency risk. This is an incomplete argument for at least two reasons. First, even if a good is priced in US dollars, it is not necessarily the case that the price is fixed in US dollars and unresponsive to movements in the exchange rate. The clearest example of this may be trade in crude oil. On the world market, oil prices are typically quoted in US dollars, but when the US dollar exchange rate changes, the US dollar price of crude reacts almost immediately. In other words, the price of oil measured in US dollars is not necessarily more stable than the price measured in euros simply because it is quoted and invoiced in the former currency. Second, what matters for the exporter is presumably not the volatility of prices in domestic currency but the volatility of profits. Hence, if the price is fixed in terms of the exporter's currency, and the quantity demanded by the importer reacts to changes in the exchange rate, then it is uncertain how the total revenue and profits will evolve.

Even the effect of invoicing of trade in US dollars is not unambiguous. True, when an invoice specifies the price in US dollars and the quantity traded, then any exchange rate changes that intervene between the signing of the invoice and the payment for the goods will give rise to some exchange rate risk for the party of the transaction not using the dollar as its base currency. This risk can of course be hedged, but this is costly and it is therefore often asserted that the non-US trade partner is at a disadvantage. However, the cost of insuring against exchange rate fluctuations does not necessarily fall on the entity that actually pays for the insurance contract. It is well known that the incidence of a tax does not necessarily fall on the economic agent that actually collects the tax and pays it to the government. The same is true here. The cost of insuring against currency fluctuations may, in principle, be borne by the importing firm or the exporting firm regardless of the currency of invoicing, as the cost of insurance may already be included in the quoted price. Whether it is depends on the relative bargaining powers of the two parties to the transaction.

Consider now the case of trade between two partners, neither of whose home currency is the US dollar. In this case, trade costs associated with settlements and hedging will be larger, to the extent that they do not occur bilaterally but involve the US dollar as a vehicle currency. As before, whether the exporter or the importer bears the increased costs depends on their relative bargaining power. If the foreign exchange aspects of this trade could be handled bilaterally without going through the dollar, the costs could be reduced, provided that the transaction costs on this bilateral market were less than twice those of the markets involving the vehicle currency. This is, of course, the crux of the notion of the network externalities associated with the use of a vehicle currency, namely, that the increased volume of trading leads to lower per-unit transaction costs.

I conclude from this discussion that denominating, invoicing, and settling trade in a vehicle currency does indeed lead to a reduction in trade costs for trade involving the country in 
which that is the home currency. But it will also reduce trade costs for trade between third parties because of the savings associated with the use of a more efficient foreign exchange market involving the vehicle currency. The policy implication of this, therefore, is not that a country should mandate the use of its currency in trade, as this may just increase trade costs if its foreign exchange market is not sufficiently well developed. On the other hand, supporting the development of the local foreign exchange market is useful in its own right and may lead exporters and importers to change the way they denominate, invoice, and settle trade.

\subsection{Currency convertibility versus currency internationalisation}

Comprehensive international use of a currency, which I have referred to as full currency internationalisation, presupposes the absence of restrictions on international financial transactions using that currency. The reason for this is that competition between alternative currencies will eliminate those in which transaction costs are too high. Large-scale issuance of financial instruments requires the existence of liquid markets in which secondary market transactions can take place at low cost. In addition, well-functioning markets must make it possible to hedge currency and credit risks. Limits on the convertibility of a currency for international capital account transactions are likely to raise the costs to the point where it is not profitable to denominate asset trades in that currency.

Even partial currency internationalisation is likely to require substantial freedom for capital account transactions. The ability to issue bonds in one's own currency shifts the exchange rate risk to the foreign creditor. It is doubtful whether such bond issues will take place on a significant scale unless a market exists for hedging the currency risk. While it is possible that off-shore markets may develop to serve this function when restrictions on currency convertibility prevent the emergence of efficient onshore markets, the scale and liquidity of the international bond issues will suffer from the constraints on capital account transactions.

It is unlikely that a currency that is subject to restrictions on international financial transactions will voluntarily become widely used, even for trade in goods. This is because such trade still involves considerable elements of a purely financial nature, such as trade financing and hedging of exchange rate risk. If these types of transactions are very costly or not allowed by law, the use of the currency, even in current account transactions, is likely to be limited.

These considerations suggest that before the desirability of currency internationalisation is evaluated, it is necessary to weigh the benefits and costs of liberalising capital movements. This is an issue which has generated a lively debate in recent years, not least because of the experiences in Asia during the 1997-98 crisis and its aftermath. As many of the arguments are by now well known, only the main elements will be noted here. ${ }^{8}$

The case for free movement of capital across borders is an extension of the argument for having well-functioning domestic financial markets. The ability to trade assets with the rest of the world has the potential to increase the efficiency of resource allocation. International borrowing and lending enhances the possibility for international risk-sharing, leading to smoother consumption streams, and it makes it possible to take advantage of investment opportunities without altering consumption patterns. In addition, two-way asset trade increases the scope for portfolio diversification taking advantage of the non-perfect synchronisation of asset price movements across jurisdictions. Exposure to competition from foreign suppliers of financial services may also lead to efficiency improvements in domestic financial institutions.

8 See Committee on the Global Financial System (2009) for a recent overview. 
While acknowledging these efficiency gains, a number of economists and policymakers have cautioned against removing all controls on capital flows lest it lead to macroeconomic instability. The concern is that sudden starts and stops of capital flows will lead to changes in the exchange rate, interest rates, or domestic financial conditions more generally, thereby increasing volatility in domestic output and real income.

This is not the place to take a stand on what the net effects of liberalising capital movements are, as this is likely to depend on a number of country-specific factors such as the health and efficiency of the domestic financial system, the sophistication of legal and regulatory institutions, and the size of the economy. The point of the discussion is simply to indicate that free movement of capital is distinct from currency internationalisation and must precede it. For this reason, it is premature to discuss policies to promote currency internationalisation before it has been decided that restrictions on capital account transactions should be removed. Furthermore, an evaluation of the benefits of currency internationalisation must take, as the starting point, a situation of full financial integration of the economy with the rest of the world.

\subsection{The incremental benefits of currency internationalisation}

To discuss the incremental benefits that a country might reap from internationalisation of its currency over and above those that stem from its integration into the world financial market. I will start by comparing simple financial integration with what I have called partial currency internationalisation and then proceed to considering the case of full currency internationalisation.

When I refer to a country (country $A$, to facilitate reference) moving from simply being fully integrated in the world financial market to having its currency partially internationalised, I mean a situation where residents of country $A$ can not only borrow and lend internationally in the dominant international currency, the dollar at present, to a situation where country A can issue debt denominated in its own currency on the world market. This opens three new avenues for potential welfare gains. First, it makes it possible for foreign residents to include liabilities of country A denominated in country A's currency in their portfolios, which should increase the total demand for such securities. The required return for holding them should fall, constituting a gain for country A. The gain for the rest of the world is represented by the greater choice of assets in which it can invest. Second, a larger pool of investors should increase trading in the secondary market for country A's securities, making it more liquid, thereby reducing the price impact of demand shocks. Third, being able to borrow internationally in their own currency reduces the likelihood of currency mismatches on the books of domestic firms. ${ }^{9}$

At the same time, the interest rates on country A's liabilities are now determined more directly in the world capital market, which increases the sensitivity of domestic financial conditions to developments in the rest of the world. Whether this is to be considered a positive or negative development is really the same issue as whether increasing capital account liberalisation has a positive or negative effect on the domestic economy. Judging this aspect of currency internationalisation is therefore just an extension of evaluating the desirability of capital account convertibility.

9 It could be argued that liabilities denominated in the international currency could be hedged in the forward or swap markets, which would make it possible to avoid currency mismatches even if it was not possible to source funds denominated in the domestic currency on the international market. But in this latter case, it is unlikely that a liquid forward or swap market would exist in the first place. 
What about moving from partial to full currency internationalisation, ie to a situation where third parties are using the currency of country A in financial contracts? The third parties must obviously find this profitable, essentially because it would expand the asset and liability universe, and hence bring potential diversification gains, otherwise they would not do it. For country $A$, the increased international use of its currency would expand the size of its foreign exchange market, make it more liquid and reduce transaction costs for both trade in goods and assets.

What can be said about the relative size of the benefits associated with financial integration, partial currency internationalisation, and full currency internationalisation? I conjecture that the greatest efficiency gains will come from the first of these, ie the opening of the country's financial markets to those of the rest of the world. Next in importance will be the gains associated with the ability to issue debt in the international market that is denominated in the home currency. But this remains conjecture, as I now turn to the question of whether the gains from currency internationalisation are sufficient to make a case for policy intervention focused on this goal.

\subsection{A case for policy intervention?}

In view of the benefits that are associated with the international use of a country's currency, what, if anything, should policymakers do to promote it? The literature suggests that economic size, the sophistication of the domestic financial market and stable macroeconomic policies (especially low inflation) ought to be important determinants of currency internationalisation, and empirical evidence is generally supportive. As these attributes are desirable in and of themselves, they should arguably be pursued for their own sake, no matter what their effect on currency internationalisation.

What about more directly focused policies? In general, whether or not there is a case for public policy to influence private sector choices depends on the existence of externalities or spillover effects that render the market-determined outcome inefficient. What might these externalities be in the context of currency internationalisation? Recall that one of the benefits of currency internationalisation is that it may help reduce the currency mismatch of domestic debtors if it makes it possible for them to issue domestic currency denominated debt abroad. As such, it could have a positive impact on domestic financial stability in general, which would then represent a positive externality justifying policy intervention. This intervention could, for example, take the form of regulatory measures that would make it more attractive for domestic financial institutions to issue domestic currency denominated debt abroad.

Decreasing cost of establishing an international market for domestic currency denominated debt could constitute another potential justification for government intervention. Initially, high transaction costs and limited market liquidity may constitute a hurdle for the development of an offshore bond market denominated in the domestic currency or an onshore market for domestic currency bonds issued by foreign borrowers. Official support for the establishment of such markets may then be justified to the extent that it succeeds in increasing liquidity and reducing transaction costs. Such support may take the form of backing the creation of trading platforms or allowing foreign issues denominated in the domestic currency to be used as collateral in discount window operations with the central bank.

While these examples show that it is possible to find justifications for government assistance to currency internationalisation, it should be clear that any such assistance should be designed to align private and public benefits. This would seem to rule out more invasive measures aimed at mandating the use of the domestic currency in international transactions. Such attempts might well increase the cost of international transactions for domestic economic agents, and may even backfire, as such decrees may be seen as a reversal of financial openness which is a sine qua non for currency internationalisation to take hold in private sector transactions. 


\section{How many international currencies can there be?}

Is it possible to have more than one international currency? If so, what about three, four, five, or 10 international currencies? I am referring here to what I have called fully internationalised currencies, namely those which are used by third parties in some of their financial and nonfinancial transactions. Empirical investigations that measure currency internationalisation by the share of official reserve assets denominated in a particular currency implicitly acknowledge that there can be several international currencies. On the other hand, some theoretical arguments relying on decreasing cost, for example due to network externality effects, to the adoption of a currency in international transactions suggest that in a stable equilibrium there will be only one winner. So what is the countervailing force? I conjecture that it is the gain from diversification. Borrowers as well as lenders may find it useful to be able to diversify currency risk by issuing or holding assets that are denominated in different currencies. If this is right, then the transaction cost reduction associated with having only one international currency could be more than offset by the diversification gains from having several.

Let us think of the average cost associated with the use of a currency as a negative function of that currency's market share in international transactions. If there are no benefits from diversity, the currency would become the only international currency. But let us suppose that there is some benefit from diversity: then it is possible to have an equilibrium where more than one international currency will be used. If the average cost curve becomes sufficiently flat, even when the domain covered by the currency is substantially smaller than the total value of international transactions, there may be room for several international currencies. It does not strike me as far-fetched to posit that improved transaction and payment technologies have led to the exhaustion of most economies of scale at a relatively moderate size of transaction volumes relative to the total current volume of international transactions. The situation may have been different before the advent of large-scale electronic trading, when trades were conducted by telegraphic transfer. At that time, the simple image of network externalities, in which one would want to trade in the currency that everyone else was using, might have been accurate. But now, international bond traders sit in front of screens and are actually trading in many currencies almost simultaneously. The sophisticated trading platforms have made the networks much wider than before, and the international system is therefore able to support more than one fully internationalised currency.

It is therefore quite possible that the euro and the dollar, for example, will coexist in the future without any cataclysmic event leading to the replacement of the dollar as the international currency. In fact, we might very well be entering an era where several international and regional currencies will subsist as transaction costs decline due to improved trading platforms and payment infrastructures. ${ }^{10}$

If we consider what I have called partially internationalised currencies, it is even more likely that many currencies will enter that category, in the sense that many countries will be able to issue international bonds denominated in their own currency. The same principle would seem to apply here; improved transaction technology has reduced the natural advantage of the once dominant currency, so that diversification gains are more likely to offset it. What prevents most currencies from becoming fully internationalised is the size of the country and the size of its financial market.

Looking at Asia, various degrees of currency internationalisation are already present in the region. The yen, the Australian dollar and the New Zealand dollar are already used

10 Eichengreen (2005) reaches a similar conclusion. 
extensively in international transactions, even between third parties. ${ }^{11}$ Other currencies in the region are also used to various extents. Could one currency become dominant? I would argue that this is essentially a question of the size of the domestic financial market involving that currency, provided that the prerequisites that I have mentioned above have been met. This suggests that the renminbi could one day become a truly international currency. Should the other countries in the region, or other countries in the world, worry? In other words, will an internationalised renminbi confer an "exorbitant" privilege on China? I would argue not.

The term "exorbitant privilege" was coined at a time when exchange rates were mostly fixed against the US dollar, which therefore played a particular role at the centre of the system. This was an advantage for the United States in that it could set its monetary policy as it saw fit for internal purposes, whereas other countries had to adjust their policies to maintain the exchange rate pegs. The present situation is different, at least for countries which have adopted monetary policies focused on domestic objectives and have allowed their exchange rates a substantial degree of flexibility. They do not have to absorb large amounts of liabilities of the countries with internationalised currencies unless they choose to do so. The gains from having an internationally used currency are certainly present, but they are not, in my opinion, exorbitant, nor are they at the expense of other countries.

\section{Concluding remarks}

Capital account convertibility and currency internationalisation are two distinct concepts. Substantial international use of a currency in merchandise trade or in the denomination in bond issuance presupposes the absence of significant controls on capital account transactions. Liberalisation of such transactions must therefore logically precede attempts to increase the international role of a currency.

The benefits from currency internationalisation per se, ie those that go beyond the benefits of capital account liberalisation, can be linked to diversification gains associated with a wider investor base, risk management opportunities as a result of the possibility of issuing debt on the international market in one's own currency, and lower transaction costs resulting from a larger size of the market involving the domestic currency. Although these gains are genuine, it is an open question whether public policy should attempt to promote the internationalisation of the domestic currency beyond establishing preconditions such as a deep and dynamic domestic financial market, a well-respected legal framework for contract enforcement, and stable and predictable macro and microeconomic policies. The evolution of the international role of the euro, the yen, the Australian dollar and the New Zealand dollar shows that currency internationalisation does not depend on special government encouragement but will take place spontaneously when the required preconditions are met and if it is to benefit of economic agents engaged in international transactions.

\section{References}

Battellino, R and M Plumb (2009): "A generation of an internationalised Australian dollar", presented at the BoK/BIS seminar on Currency internationalisation: lessons from the global financial crisis and prospects for the future in Asia and the Pacific, Seoul, 19-20 March.

11 See the papers on the Australian dollar (Battellino and Plumb (2009)) on the yen (Tagaki (2009)) as well as the panel presentation by Grant Spencer on the New Zealand dollar. 
Chen, H, W Peng and C Shu (2009): "The potential of the renminbi as an international currency: what we can learn from international experience", presented at the BoK/BIS seminar on Currency internationalisation: lessons from the global financial crisis and prospects for the future in Asia and the Pacific, Seoul, 19-20 March.

Chinn, M and J Frankel, (2008): "The euro may over the next 15 years surpass the dollar as leading international currency" (available at: http://ksghome.harvard.edu/ jfrankel/EuroVs\$IFdebateFeb2008.pdf).

Committee on the Global Financial System (2009): "Capital flows and emerging market economies", CGFS Papers, no 33, Bank for International Settlements.

Eichengreen, B (2005): "Sterling's past, dollar's future: historical perspectives on reserve currency competition", NBER Working Paper, no 11336, May.

Kenen, P (2009): "Currency internationalisation: an overview", presented at the BoK/BIS seminar on Currency internationalisation: lessons from the global financial crisis and prospects for the future in Asia and the Pacific, Seoul, 19-20 March.

$\mathrm{Li}, \mathrm{D}$ and L Liu (2007): "RMB internationalization: an empirical analysis", presentation at the Hong Kong Institute of Monetary Research Conference on Currency internationalization: international experiences and implications for the renminbi, Hong Kong SAR, 15-16 October.

Tagaki, S (2009): "Internationalizing the yen, 1984-2003: unfinished agenda or mission impossible?", presented at the BoK/BIS seminar on Currency internationalisation: lessons from the global financial crisis and prospects for the future in Asia and the Pacific, Seoul, 19-20 March. 